\title{
GROUND WATER QUALITY IN AND AROUND BOMMASANDRA INDUSTRIAL AREA IN ANEKAL TALUK IN BANGALORE
}

\author{
Revanasiddappa M \\ Professor, Dept. of Engineering Chemistry \\ PES University, Electronic City Campus \\ Bangalore, Karnataka, India
}

Rohith G

B.E. Dept. of Computer Science \& Engineering PES University, Electronic City Campus

Bangalore, Karnataka, India

\section{Gajanan M Kamat}

B.E. Dept. of Electronics \& Communication Engineering PES University, Electronic City Campus

Bangalore, Karnataka, India

\author{
Nishanth S \\ B.E. Dept. of Computer Science \& Engineering \\ PES University, Electronic City Campus \\ Bangalore, Karnataka, India \\ Basanagouda S Hadimani \\ B.E. Dept. of Computer Science \& Engineering \\ PES University, Electronic City Campus \\ Bangalore, Karnataka, India \\ Manas Advaith V \\ B.E. Dept. of Computer Science \& Engineering \\ PES University, Electronic City Campus \\ Bangalore, Karnataka, India
}

Abstract- Bommasandra area in Bangalore, Karnataka State, India is facing deterioration in the quality of groundwater and the quantity of water is being depleted to a greater extent. In this area, groundwater is the primary source of water supply. It is generally extracted through deep tube wells from shallow and deep aquifers. Bommasandra area though being a residential and municipal area, it has several industries and has many ongoing commercial activities. This has resulted in different types of wastes being generated which have further adversely affected the quality of the groundwater in the area. So, there is a need to study and understand the quality of the groundwater and its condition. In this paper, a specific area is selected to show different special variability factors such as chemical, physiological and biological. These factors are further defined by using parameters like $\mathrm{pH}$, turbidity, electrical conductivity, chemical oxygen demand (COD) and total hardness. A chemical method of analysis is generally done to define these parameters. The analysis thus obtained after studying the groundwater in Bommasandra area reveal that there is a need for the treatment of water before consumption. These results are very beneficial and helpful for the planners and decision makers for the sustainable and effective use of groundwater resources and its management.
Key words- Turbidity, pH, Total Hardness, Electrical Conductivity, Chemical Oxygen Demand

\section{INTRODUCTION}

Groundwater is recharged from the surface. Groundwater is cost effective, convenient and less exposed to pollution than water at the surface but still certain problems have lessened the applications of groundwater around the world. Polluted groundwater is not so easily seen and it is more difficult to clean up when it is compared to the pollution in the water sources like rivers and lakes (Suresh $\mathrm{T}$ et al. 2009; Revanasiddappa M et al. 2019; Aditya G et al. 2015). There have been various threats to human health these days due to unsanitary conditions such as open drains which dispose waste water into various natural bodies. The availability of ground water and its quality have been exploited especially in developing countries such as India due to rapid urbanization and improper waste disposal. Studies conducted by WHO organization shows that about $80 \%$ of all the diseases in human beings are caused by water (Mangukiya et al. 2012; Nagarajappa et al. 2011; Shivasharanappa et al. 2011; APHA, 2003). Water quality index is one of the most significant tools, which effectively communicates all kinds of information related to the quality of water present as ground water. There are five parameters which are considered for calculating WQI. These are as follows $\mathrm{pH}$, total hardness, total dissolved solids, COD and electrical conductivity. In order to predict the 
quality of water, the results are further analysed using WQI method. This method is an effective and a very useful way for assessing the quality of water. It also gives the complete information on the overall quality of water available.

\section{Population density and growth rate:}

According to the provisional reports of census of India, population of Bommasandra in the year 2011 was 28353, out of which male were about $15973(56 \%)$ and females were about 12380 (44\%). Average literacy rate in Bommasandra city was about $72 \%$, of which female and male literacywas about $61 \%$ and $80 \%$ respectively. The No. of children in the age group between 0-6 in Bommasandra city was about 2500 as per the Census India report in the year 2016. More than $85 \%$ of the population speak Kannada in Bommasandra city.

\section{Material And Methods}

\section{a) Study area - Bommasandra}

Bommasandra is a part of Anekal Taluk in Bangalore (South District) in Karnataka. It is located on the coordinates: $12.82^{\circ} \mathrm{N}$ and $77.69^{\circ} \mathrm{E}$. Bommasandra has well-established industries in and over its lands. The water samples were collected around this industrial area. It has a busy environment and the temperature throughout the year is usually less than $36^{\circ} \mathrm{C}(309 \mathrm{~K})$. Usually the rainfall is about $859 \mathrm{~mm}$ in Bangalore annually.

\section{b) Sample collection in the study area}

Preparation of ground water sampling trips was done carefully with planning in order to save time and to reduce difficulties that usually occur in the field of work being carried out. A thorough preparation needs to be done in the office and laboratory before sample collection in order to maintain correct sampling procedure. During sample collection, preservation and shipment must be done in order to ensure a high quality sample. Each sample bottle needs to be thoroughly cleaned and protected from any kind of contamination. In order to remove any kinds of mineral deposits in hoses or support container vessels, it has to be thoroughly rinsed using Filtering equipment. The sample containers and hoses are to be acid-washed and rinsed several times with deionised water for organic analyses. Grab sampling has been adopted to collect groundwater samples. A total of 16 ground water samples were collected in polythene containers each of about 2 litres capacity for chemical analysis after pumping out sufficient amount of water from the source, so that the sample collected can be served as a representative sample. These samples collected were further transported to the laboratory environment. In the month of January in the year 2020, groundwater samples of ten bore wells were collected from Bommasandra.

c) Parameters under monitoring
The groundwater samples were collected from different bore wells and study of the certain factors say-pH, Electrical Conductivity, Chemical Oxygen Demand (COD), Total Hardness and Total Dissolved Salts using standard procedures and the values were calculated through careful standardization (APHA, WPCF 1989; National Research Council, 1993).

\section{EXPERIMENTS AND DISCUSSIONS}

\section{a) pH:}

$\mathrm{pH}$ measures hydrogen concentration. It indicates the acidity or neutrality or alkalinity of a solution. $\mathrm{pH}$ scale 0 to 14. The solution is said to be basic or alkaline if the $\mathrm{pH}$ is more than 7 and the solution is said to be acidic if the $\mathrm{pH}$ is less than 7 and the solution is neutral if the $\mathrm{pH}$ is exactly 7 . The neutrality of the solution is due to the equal amounts of $\mathrm{H}+$ ions and $\mathrm{OH}$ - ions in the pure water. The $\mathrm{pH}$ level exceeds more than 14 for very strong bases and goes less than 0 for very strong acids. $\mathbf{p H}=-\log _{10}[\mathbf{H}+]$ and the unit is moles per litre.

\section{b) Electrical Conductivity:}

The conductivity of water is defined as the ability of it to allow ions to move freely through it on application of voltage across it. Natural water usually contains dissolved ionic salts and these ions provide a pathway for the flow of charges through the solution. Hence it conducts electricity. Its SI units are $S \mathrm{~cm}^{\wedge}-1$. The conductivity cell was washed with deionized water. The conductivity cell of conductometer was immersed in a certain quantity of each water sample and conductance values of all the samples were noted. The conductivities of the samples were calculated by multiplying the conductance value with a multiplying factor called cell constant which is $1 \mathrm{~cm}^{-1}$.

\section{c) Chemical Oxygen Demand (COD):}

COD (Chemical Oxygen Demand) is the amount of oxygen required to degrade the chemical and biological present in the water. The SI units of COD are milligrams per litre $(\mathrm{mg} / \mathrm{L})$. COD are measured by titration, using an indicator solution. A weighed quantity of FAS (Ferrous Ammonium Sulphate) crystals was taken in a $250 \mathrm{ml}$ volumetric flask. $1 / 2$ test tube of 1:1 sulphuric acid was added followed by small amount of water to dissolve the salts and the standard solution was prepared by making up to the work.

Blank Titration: $10 \mathrm{ml}$ of potassium dichromate solution was pipetted out into a clean conical flask. $3 / 4^{\text {th }}$ test tube of $1: 1$ sulphuric acid was added.3-4 drops of Ferroin indicator was added. The colour of the solution changed to bluish green. This was taken in a burette and titrated against standard FAS solution until there is change in colour to reddish brown. The burette reading was noted down and the titration was repeated to get concordant values. 


\section{International Journal of Engineering Applied Sciences and Technology, 2020 \\ Vol. 5, Issue 4, ISSN No. 2455-2143, Pages 410-414 \\ Published Online August 2020 in IJEAST (http://www.ijeast.com)}

Back Titration: $25 \mathrm{ml}$ of industrial waste water was pipetted out into a clean conical flask. $10 \mathrm{ml}$ of alkaline $\mathrm{K}_{2} \mathrm{Cr}_{2} \mathrm{O}_{7}$ solution was added. 3-4 drops of Ferroin indicator was added. The colour of the solution changed to bluish green. This was taken in a burette and titrated against standard FAS solution until there is change in colour to reddish brown. The burette reading was noted down and the titration was repeated to get concordant values.

Weight of FAS crystals $=\mathrm{W} g$

Therefore, Normality of FAS $=\left(\mathrm{W}^{* 4}\right) / 392.14=\mathrm{Z} \mathrm{N}$

FAS Volume used in the blank titration $=\mathrm{Y} \mathrm{cc}$

FAS Volume used in the sample titration $=\mathrm{X} \mathrm{cc}$

Therefore, COD of the water sample $=(8 *(\mathrm{Y}-\mathrm{X}) * \mathrm{Z} * 1000) / 25$ mg of Oxygen/L

\section{d) Total Hardness of water:}

Total hardness is the sum of temporary hardness (due to HCO3- of $\mathrm{Ca}^{2+}$ and $\mathrm{Mg}^{2+}$ ) and permanent hardness (due to $\mathrm{Cl}^{-}$, $\mathrm{SO}_{3}{ }^{2-}$ of $\mathrm{Ca}^{2+}$ and $\mathrm{Mg}^{2+}$ ). Ethylenediamine tetra acetic acid (EDTA) is a reagent, which reacts with metal ions like $\mathrm{Ca}^{+2}$, $\mathrm{Mg}^{+2}$ forming a complex compound. Therefore, this reagent can be used to determine the concentration of hardness causing substances. A known amount of $\mathrm{Na}_{2}$ EDTA salt was taken in $250 \mathrm{ml}$ volumetric flask and $3 \mathrm{ml}$ of ammonia was added. Then the distilled water was added to dissolve the salt completely and added up to the mark and the standard solution was prepared. A $3 \mathrm{ml}$ of $\mathrm{NH}_{4} \mathrm{OH}-\mathrm{NH}_{4} \mathrm{CL}$ buffer followed by Eriochrome black-T indicator was added to $25 \mathrm{ml}$ of water sample in a clean conical flask.

Titration of this was done against the standard $\mathrm{Na}_{2}$ EDTA solution till the color of the solution changed from wine red to clear blue and the titer value was noted as furnished below:

Weight of $\mathrm{Na}_{2}$ EDTA salt $=\mathrm{W}$ g

Therefore, Molarity of $\mathrm{Na}_{2} \mathrm{EDTA}=(\mathrm{W} * 4) / 372.24=\mathrm{Z} \mathrm{M}$

Volume of $\mathrm{Na}_{2}$ EDTA consumed by $25 \mathrm{cc}$ of water sample $=$

$$
\mathrm{X} \mathrm{cc}
$$

Therefore, Total hardness $=\left(\mathrm{X}^{*} \mathrm{Z} * 10^{5}\right) / 25 \mathrm{mg} / \mathrm{L}(\mathrm{ppm})$ of

\section{e) Total Dissolved Salts:}

TDS stands for total dissolved salts, and it is the total sum of all the individual amount of the dissolved salts present in the industrial water. TDS is a mixture of both organic and inorganic salts. The initial weight of the dry crucible is noted $10 \mathrm{ml}$ of a sample of water is poured into a crucible. The water is evaporated and the crucible is allowed to cool. The weight of the crucible is recorded again. The difference between the two weights gives an estimate of the

TDS of the water sample:

Weight of the empty crucible $=\mathrm{W} 1 \mathrm{~g}$

Weight of the crucible after evaporation $=\mathrm{W} 2 \mathrm{~g}$ TDS $\left.=\left((\mathrm{W} 2-\mathrm{W} 1) \times 10^{6}\right) / 10 \mathrm{ppm}\right)$

The rating of water for TDS level $(\mathrm{mg} / \mathrm{l})$ is given by-

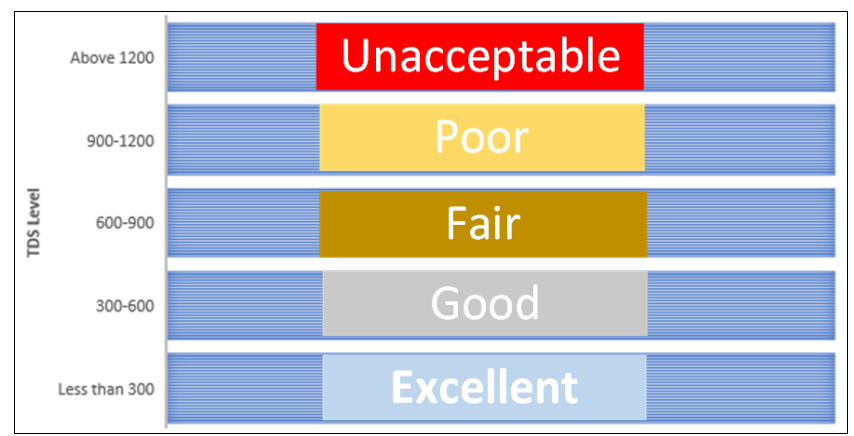

Fig.1: Rating of Water for TDS level (mg/l)

\section{OBSERVATIONS}

Table- 1: Measurements of chemical and physical parameters of bore well water samples

\begin{tabular}{|c|c|c|c|c|c|}
\hline Sample & pH & $\begin{array}{c}\text { Condu } \\
\text { ctivity } \\
(\text { S/cm })\end{array}$ & $\begin{array}{c}\text { COD } \\
(\mathrm{mg} / \\
\text { L) }\end{array}$ & $\begin{array}{c}\text { Hardness } \\
(\mathrm{mg} \text { of } \\
\text { CaCO3) }\end{array}$ & $\begin{array}{c}\text { TDS } \\
(\mathrm{mg} / \mathrm{L})\end{array}$ \\
\hline 1 & 6.17 & 1.13 & 1.45 & 1194 & 560 \\
\hline 2 & 6.63 & 1.36 & 2.27 & 1217 & 950 \\
\hline 3 & 6.98 & 1.92 & 1.36 & 1349 & 430 \\
\hline 4 & 5.87 & 1.46 & 1.09 & 1139 & 750 \\
\hline 5 & 6.81 & 1.34 & $\mathbf{0 . 4 5}$ & 1327 & 180 \\
\hline 6 & 6.23 & 1.56 & 2.63 & 1210 & 390 \\
\hline 7 & 7.01 & $\mathbf{0 . 9 3}$ & 2.27 & 1366 & 860 \\
\hline 8 & 7.22 & 1.58 & 2.91 & 1405 & 510 \\
\hline 9 & 6.44 & 2.33 & 1.82 & 1269 & 670 \\
\hline 10 & 5.95 & 1.47 & 3.36 & 1152 & 1220 \\
\hline
\end{tabular}

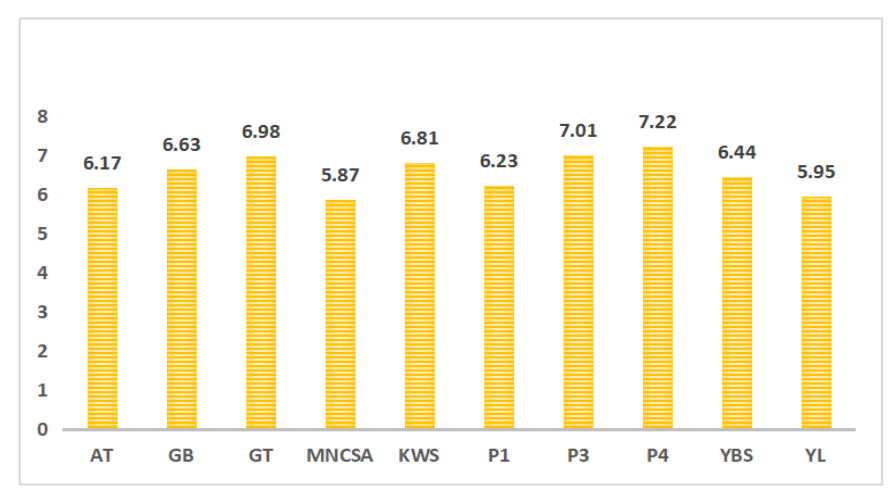

Fig.2: $\mathrm{pH}$ of the various water samples 


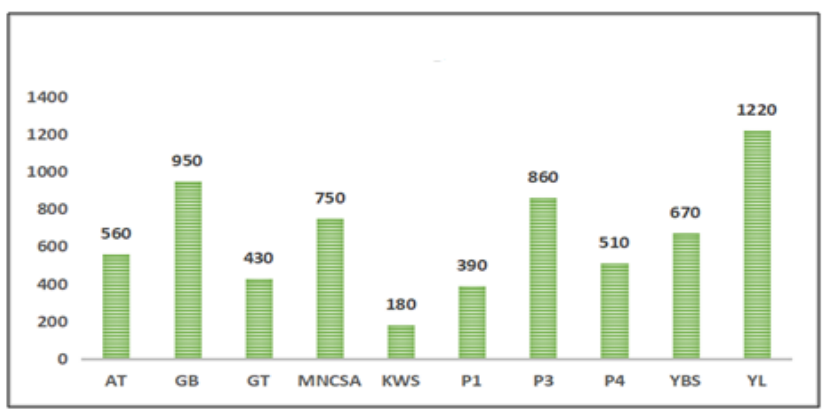

Fig.3: Total Dissolved Salts (TDS) measure of various water samples

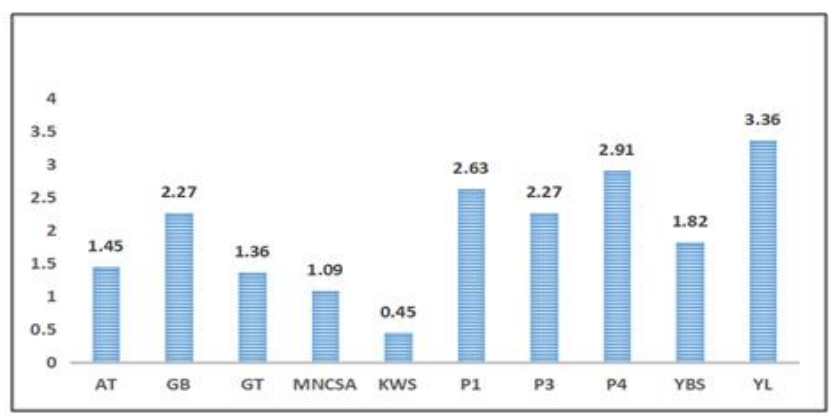

Fig.4: Chemical Oxygen Demand (COD) of various water samples

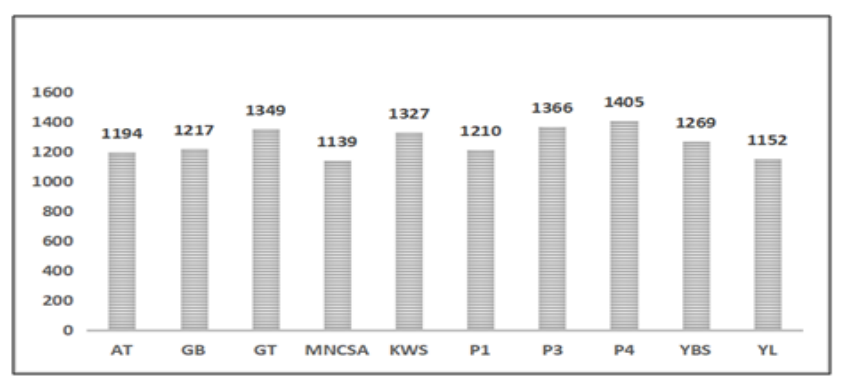

Fig.5: Total Hardness (TH) of the water samples

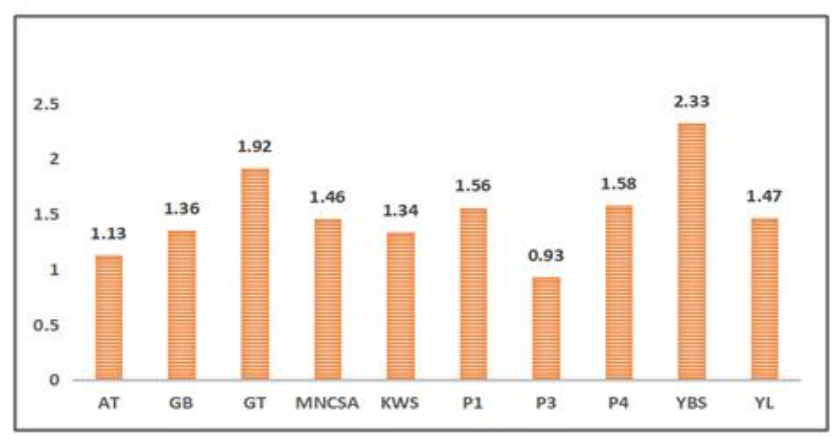

Fig.6: Conductivity of tested water samples.

Legend: AT-Anjaneya Temple; GB-Gouda Building; GT-Ganesha Temple; MNCSA - MNC Sports Academy; KWS - Kaveri Water Supply; P1-Park 1 ( RK Township); P3-Park 3 ( RK Township); P4Park 4 (RK Township); YBS -Yarandahalli Bus Stop; YLYarandahalli Lake

\section{CONCLUSION}

The results obtained, indicate that most of the quality parameters for bore well water were much beyond the permissible limits in the industrial area and its environment. The overall view of the WQI and its value was poor for the present study zone. In case of any bore well water quality treatment programme, the main point of consideration is to bring the WQI below 100.

Compressive sewerage system must be developed for safe disposal of wastes and to safeguard ground water quality in the area of study.

The bore well water was crystal clear, odourless and palatable and was of salty taste at few sample points. The bore well water was moderately hard in almost all of the sampling points. The total hardness exceeded the permissible limit at many places in about 16 sampling stations. The higher hardness was observed mainly due to disposal of municipal and sewage waste.

The TDS levels of the ground water samples in Bommasandra industrial area and its environments were within the permissible limit. The results of physicochemical analysis of ground water of Bommasandra industrial region for year 2020 shows that, the observed mean $\mathrm{pH}$ values in Bommasandra industrial region are well within the permissible limit.

Based on observations and discussions, groundwater's quality is not constant throughout, not even for a range of 1 kilometre. The main reason for these changes is due to the presence of varying works occurring in different areas. The presence of industries near the wells pollutes the groundwater. The industries and factories release their wastes into the nearby lakes, the water in these lakes soak into the bed and hence enter the groundwater thereby deteriorating the purity of groundwater. Water near the industries has $\mathrm{pH}$ less than 7 indicating the acidic nature of water. This water is unfit for drinking, washing etc., which causes health problems.

The increase in pollutants in water increases the oxygen demand for the oxidation of the organic matter. The experimental observations show that there are presence of various ions and chemical impurities in the water samples due to which the water is not suitable for drinking and agricultural purposes.

Hence, there is a need to increase the purity of water by using appropriate technologies. Water may also be poor in quality due to contamination of sewage and drainage water. This further shows that there is a possibility of contamination of bore well water due to percolation of polluted surface water. Therefore, the water of Bommasandra is considered as POOR WATER based on WQI. 


\section{ACKNOWLEDGMENT}

The authors extend their acknowledging to The Principal, the Management of the College, PES University, Electronic City Campus, Bangalore for their encouragement and support to carry out this research study. The authors express their profound thanks and acknowledge all the authors and contributors of research articles and other reports which has been referred and cited in this research article. Also, the authors thank the editorial of Hillgrove Research Pvt. Ltd., Coimbatore, for their editorial service.

\section{REFERENCES}

1. Suresh T, Kottureshwara N M, Revanasiddappa M, "Assessment of Groundwater Quality in and Around Bellary city of Karnataka, India", Journal of Nature, Environment and Pollution Technology, Vol. 8,No.4, pp 683- 692, 2009

2. Revanasiddappa M, Deepak N, Sujan Reddy J S, Jayanth Raj R, "Ground Water Quality in and around Jigani Industrial Area in Anekal Taluk in Bangalore", American International Journal of Research in Formal, Applied \& Natural Sciences, 28(1), 2019, pp. 07-09, 2019

3. Aditya G, Sathvik A S, Kakumanu Venkata Sai Sumanth, Grandhi Pavan Kumar, Chakradhar B, Pradeep Raja K P, Revanasiddappa M, "Spatial Analysis of Groundwater Quality Using GIS System in Jnanabharathi Ward. No 129, Bangalore, Karnataka State", International Journal of Science and Research (IJSR), pp 163-167, 2015

4. Mangukiya R., Bhattacharya T., Chakraborty S, "Quality Characterization of Groundwater using Water Quality Index in Surat City, Gujarat, India", International Research Journal of Environment Sciences, 1(4): 14-23, 2012
5. Nagarajappa D P., Rajappa B., Manjappa s., and Puttaiah E T., (2011), "Physico chemical analysis of underground water of Hariharataluk of Davanagere district, Karnataka, India", Advances in applied science research, 2(5): 143-150.

6. Shivasharanappa, Srinivas P, Mallikarjun Huggi S, "Assessment of Ground Water Quality Characteristics and Water Quality Index (WQI) of Bidar City and its Industrial Area, Karnataka State, India", International Journal of Environmental Ssciences, 2(2): 965-976, 2011

7. American Public Health Association, "Standard method for examination of water and wastewater specifications", 6, 19e, Washington DC, 2003

8. American Public Health Association, American Water Works Association, Water Pollution Control Federation, "Standard Methods for the Examination of Water and Wastewater", 17e, 1989.

9. National Research Council, "Groundwater vulnerability assessment: contamination potential under conditions of uncertainties", National Academy Press., Washington, D.C., 185pp, 1993 